\title{
An emergentist view on functional classes
}

\section{Introduction}

Building on Manzini 2014, Manzini \& Savoia 2014, this paper aims to challenge the hypothesis that function words fall into classes. Furthermore, I show that the distribution and behaviour of Romance pronouns does not provide conclusive evidence to the claim that so-called classes result from the internal make-up of function elements.

The distinction between classes of function words is often conceptualised in terms of inner syntax: strong elements are conceived as extended phrases, while clitics correspond - at least in the latter stage of their derivation - to a deprived structure, possibly to a single head exhibiting an affixlike behaviour. The correlation between the behaviour of function words and their syntactic makeup was advanced by Kayne 1975, who argued that clitics are heads inasmuch as they cannot be coordinated, focused, modified, used in isolation, etc. Kayne 1983 argued that certain clitics noticeably, French subject clitics - are in fact phonological clitics as they show cues of phrasal behaviour. The status of phonological clitics has been revised in comparison to the status of Germanic weak pronouns, e.g. German es, which cannot be coordinated, modified, etc., although they are not bound to a specific host or to a dedicated syntactic position (see Holmberg 1986, 1991 a.o.). The Germanic data led Cardinaletti 1991, 1994, 1998; Cardinaletti \& Starke 1996, 1999 to a more articulated typology of deficient elements by individuating a third class of pronouns, which Cardinaletti and Starke term weak. Inter- and intra- linguistic variation follows from the distribution of pronominal forms across the three classes, as exemplified in the following table, which illustrates the status of certain Italian and German pronouns (from Cardinaletti \& Starke 1996: 27, 29):

\begin{tabular}{lllll} 
& \multicolumn{2}{c}{ Italian } & \multicolumn{2}{c}{ German } \\
& 3.sg.m.dat & 3.pl.dat & 3.sg.m.acc & 3.sg.n.acc \\
Clitic & gli & - & - & - \\
Weak & - & loro & ihn & es \\
Strong & a lui & a loro & ihn & -
\end{tabular}

As previously mentioned, classes are often modelled in terms of syntactic constituency. Functional elements are stored in the lexicon as triplets formed by a syntactic subtree, containing $a$ bundle of $\varphi$-features, associated with a phonological exponent (see also Starke 2009). Elements with the same syntactic subtree form a class, although they may differ from one another in terms of the features they express. In Cardinaletti \& Starke's 1999 formulation, clitic and weak pronouns differ from strong pronouns in lacking the outer functional layer $\mathrm{C}_{\mathrm{L}}$ (where $\mathrm{L}$ stands for any Lexical category), which allows the pronoun to be coordinated, modified, contrasted, etc. Furthermore, clitics lack a further layer (namely, $\Sigma_{\mathrm{L}}$ ), whose absence correlates with syntactic and morphophonological properties, e.g. doubling, prosodic deficiency, etc.:
a. Strong
b. Weak
c. Clitic
$\left[\mathrm{C}_{\mathrm{L}}\left[\Sigma_{\mathrm{L}}\left[\mathrm{I}_{\mathrm{L}} \mathrm{LP}\right]\right]\right]$
$\left[\Sigma_{\mathrm{L}}\left[\mathrm{I}_{\mathrm{L}} \mathrm{LP}\right]\right]$
$\left[\mathrm{I}_{\mathrm{L}} \mathrm{LP}\right]$

Dèchaine \& Wiltschko 2002 have argued for a similar tripartition, see (3), but on the basis of a different set of phenomena (predicate/argument asymmetries, binding, obviation, switch reference, etc.). However, Dèchaine \& Wiltschko's classification cuts across Cardinaletti \& Starke's, meaning that the typology is, at best, far more complicated than previously thought.

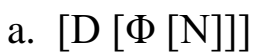
b. $[\Phi[N]]$
c. $[\mathrm{N}]$ 
Given (2) and (3), the crucial point is how to disentangle properties hinging on the internal structure of pronouns from phenomena attributable to external, clausal factors. For instance, some languages display a three-way system of possessive pronouns: Italian dialects, old Italian (Giusti 2010), and old Gascon (Rohlfs 1970:187) exhibit strong postnominal possessives, as in (22a), weak prenominal possessives, as in (22b), and, with kinship nouns, clitic possessives ${ }^{1}$, which do not cooccur with the definite article, see (22c).

(4) a el libro mio
the book my
b el me libro
the my book
'My book'
c me= mama
my= mum
'Mum'

It is worth noting, however, that the data in (4) are not per se conclusive evidence in favour of a three-way classification as the alternation between (4)b and (4)c may be ultimately due to an external factor, i.e. the peculiar syntactic behaviour of (certain) kinship nouns, which is confirmed by robust crosslinguistic evidence (Benincà 1980, Longobardi 1994). Hence, given the presence of an external, independent explanation, the hypothesis that the alternation in (4)b and (4)c follows from the internal structure of the pronoun seems rather redundant and should be discarded in compliance with Occam's razor. Analogously, I show that several other phenomena point to clauselevel explanations rather than class-based accounts.

The paper is organised as follows: section 2 summarises some of the phenomena that are normally taken as evidence for (pronominal) classes; section 3 focuses on the behaviour of clitic/weak pronouns in V2 environments; section 4 deals with doubling and resumption; section 5 addresses patterns in which the deficient pronoun is doubled by another deficient pronoun; section 6 is about climbing; section 7 examines the make-up of clitic combinations; section 8 discusses certain proclisis/enclisis asymmetries; section 9 deals with interpolation; section 10 focuses on the occurrence of clitics and weak pronouns in the complement position of prepositional phrases.

\section{Deficient pronouns and non-canonical clitics}

Many languages show a clear distinction between strong and deficient pronouns. The alternation between the two series is normally dependent on pragmatic factors (the latter usually denotes background information) and correlates with several syntactic, morphological, and phonological effects.

Several proposals have been advanced to distinguish different types of deficient pronouns, e.g. phonological vs syntactic clitics, simple vs special clitics, weak vs clitics. Definitions and criteria are not homogeneous and the taxonomies produced so far are not easily comparable.

Furthermore, differences in the syntactic make-up of pronominal forms are usually assumed to be reflected in the morphophonological make-up of pronominal exponents: roughly speaking, strong pronouns behave prosodically and syntactically like words, while clitics are monosyllabic heads exhibiting an affix-like behaviour (I am not referring here to a specific formalization of the

\footnotetext{
1 The possessive clitic occurring with kinship nouns is enclitic in Romanian, old Italian (Giusti 2010), and modern southern Italian dialects (Egerland 2013), e.g. fija-mə 'son=my', mammə=mə 'mum =my', fretə-tə 'brother =your', tsia-ta 'uncle=your', etc. (Lanciano, Abr.).
} 
hypothesis, but to a rather naïve view, which is nonetheless tacitly assumed in part of the recent literature):

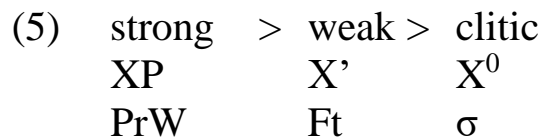

This idealised picture is often challenged by cases in which clitics can be stressed as in (6), have the same form of strong pronouns as the French enclitic in (7), do not climb in compound tenses as in (8), may be separated from the verb by certain adverbs as in (9), or occur as the complement of a (lexical) preposition as in (10).

(6) Finir-lù

(Viozene, Rohlfs 1966: 442)

To.end=it

'to end it'

(7) a. Il me le donne

(French)

He to.me $=\mathrm{it}=$ gives

'He gives it to me'

b. Donne-le-moi!

Give $=\mathrm{it}=$ to.me

'Give it to me!'

(8) I an rangiò-la.

They $=$ have fixed $=$ it.F

(Cairo Montenotte, Parry 2005)

'They fixed it.'

(9) I porti mi-lla.

$\mathrm{I}=$ bring not=it

'I'm not bringing it.'

(10) no sten ndar drio-ghe
not we.stay to.go behind=to.him/her

(Fossaltino, Vedovato \& Berizzi 2011)

'Let us not follow him/her'

(Borgomanerese, Tortora 2015a)

Do the facts in (6)-(10) challenge or support the proposed distinction into pronominal classes? Laenzlinger 1993, 1994; Ordóñez and Repetti 2006, 2014; Repetti 2016; Cardinaletti 2015a, 2015b have argued that the clitics in (6)-(10) are in fact weak elements in the sense of Cardinaletti 1991, 1998; Cardinaletti \& Starke 1999. Conversely, I argue that the phenomena in (6)-(10) end up challenging class-based accounts like (1)-(2) as none of the properties distinguishing weak from clitic pronouns, listed in (11), hold systematically across languages.

(11) a. weak pronouns can occur in the first position of V2 clauses;

b. clitics can double phrasal arguments;

c. clitics climb to the auxiliary in compound tenses;

d. clitics form tight clusters;

e. clitics are morphologically less complex than weak;

f. clitics, unlike weak elements, cannot occur as complement of Ps;

g. both weak and clitics can denote nonhuman referents.

h. weak are not subject to the Person Case Constraint

i. weak elements can bear lexical stress; 
j. weak, unlike clitics, can be omitted under coordination;

The Romance languages, including dialects and historical vernaculars, exhibit a series of counterexamples and irregularities, which will be examined in the following subsections, that may lead us to reconsider the above tests and the overall hypothesis that functional elements belong to classes defined in terms of inner syntactic structures.

\section{V2 syntax}

Weak pronouns can occupy the first position of the clause in languages with a strict V2 syntax such as German and Dolomitic Ladin. If another constituent is fronted, as shown in (13)b, then the weak element must be displaced after the inflected verb.

(12) Es ist zu teuer

It is too expensive

'It is too expensive'

(13) a. T vas gonoot a ciasa sua.

(S. Leonardo Poletto 2000: 89f.)

You go.2.SG often at home his

'You often visit him.'

b. Gonoot vas-t a ciasa sua.

Often go.2.SG=SCL at home his

'You often visit him.'

c. *Gonoot $\mathrm{t}$ vas a ciasa sua.

Often you go.2.SG at home his

Clitics, by contrast, differ from weak elements as, in V2 systems, they cannot occupy the first position of main declarative clauses. This claim follows from the syntax of medieval Romance, provided that medieval Romance languages exhibited a peculiar V2 syntax (Benincà 1983-4 a.o.; for a recent overview of the topic, see Wolfe 2016: 288). In fact, early Romance (with a certain degree of cross-linguistic variation), allowed both strict V1, especially in context of so-called narrative inversion, and disguised V1, i.e. V1 preceded by topic material.

Crucially, in these contexts, clitics must occur enclitically (the phenomenon is known as ToblerMussafia law):

(14) a Mandolli per li detti ambasciadori tre pietre nobilissime (Novellino II) he.sent=to.him through the said ambassadors three stones

b A voi le mie poche parole ch' avete intese to you the my few words that you.have heard

ho lle dette con grande fede (oFl.; Schiaffini 1926, 282)

I.have =them said with great faith

'The few words that you heard from me I pronounced with great faith.'

Given (14), one might therefore conclude that enclisis follows from the deficient structure of the clitic. This kind of explanation has been adopted by Lema \& Rivero 1991 (and revised in following works by Roberts \& Roussou 2003), although Rivero 1986 argued that old Spanish clitics 'are NP's or PP's, share the distribution of other phrasal complements, and undergo the same movement rules' (but see Martins 2003).

However, even admitting that old Romance clitics were fully-fledged clitics, the idea that $\mathrm{T}$ moves in order to prevent clitics from occurring in the first position of the clause is not very 
promising. First, if old Romance had a constraint preventing a clitic head from occurring in first position, one would not expect $\mathrm{T}$ itself to occur in first position, contra (14)a. Second, it is likely that clitic placement is the consequence, not the trigger of verb movement, which means that in (14) the verb moves independently above the clitic (and irrespectively from the clitic's structure), yielding enclisis (see, among many others, Benincà 1983-4, 1995, 2006 and references therein).

In this respect, the distribution of proclisis and enclisis in early Romance seems orthogonal to the clitic/weak distinction and it therefore does not provide any conclusive clue about the internal make-up of clitic pronominal forms.

\section{Doubling (and resumption)}

Clitic doubling is allowed in a subset of the Romance languages:
(15)
a. Le di
un regalo a mi madre.
(Spanish)
b. $*$ Le diedi
un regalo a mia
madre.
(Italian)
To.her= I.gave a gift
'I gave my mother a gift'

In standard Italian, for instance, doubling is not allowed - see (15)b - although in a lower/colloquial register doubling is tolerated, in particular when the dative clitic is clustered with an accusative one as in (16)b (Benincà 1988; for a possible explanation, see Pescarini 2014: 174):
(16) a. ${ }^{\%}$ gli ho dato un libro a Gianni (doubling)
to.them = I.have given a book to $\mathrm{G}$.
'I gave him a book (to Gianni)'
b. glie-1' ho dato a Gianni
to.them-it= I.have given to $\mathrm{G}$.
'I gave it to him (to Gianni)'

Clitic resumption is always possible, although it is worth recalling that resumption of elements other than direct objects may be optional.
(17) A Gianni, (gli) ho dato un libro (dislocation with resumption)
ToG. to.him= I.have given a book
'I gave him a book (to Gianni)'

By contrast, weak loro, unlike clitics, can neither double nor resume any dative complement (Cardinaletti 1991):

(18) a.*Ai miei amici, diedi loro un bacio. (dislocation with resumption)

To.the my friends I.gave to.them a kiss

'I gave them a kiss (to my friends)'
b. *diedi loro un bacio ai
'I gave them a kiss (to my friends)'
miei amici (doubling)
my friends

The ungrammaticality of (18)a does not probably depend on the internal structure of the pronoun as many languages allow weak pronouns to resume left-dislocated elements, see (19).

(19) a. Your book, I read it yesterday. 

b. Peter, ich werde ihn morgen sehen P. I will him tomorrow see
'I will see Peter tomorrow'

The incompatibility with doubling, on the contrary, seems a rather robust property of non-clitic elements, although it is worth recalling that the correlation between being a clitic and being a doubler is not biconditional, cf. (15). In this respect, the syntax of subject clitics is quite illuminating. For instance, Rhaeto-Romance and French subject pronouns are regarded as weak elements by Cardinaletti \& Starke as they cannot double a DP subject (at least in the formal register $^{2}$, see Palasis 2015 for a recent overview), see (20)a vs (20)b. Northern Italian dialects, by contrast, have fully-fledged subject clitics which can co-occur with a DP subject even if the latter is not dislocated (furthermore, notice that French subject 'clitics' precede the preverbal negative marker, while northern Italian dialects display the order negation - clitic):
a.*Jean il ne vient pas
(French)
b. Jean, il ne vient pas
J. he $=$ not comes NEG
'He (Jean) comes'

$\begin{array}{lllll}\text { (21) a. Giani } & \text { no } & \text { ' } 1 & \text { vien } & \text { mia } \\ \text { b. Giani, } & \text { no } & \text { ' } 1 & \text { vien } & \text { mia } \\ \text { G. } & \text { not } & \text { he }= & \text { comes } & \text { NEG }\end{array}$

(Veronese)

However, the distribution of subject clitics in several northern Italian dialects is more subtle. For instance, in Paduan, subject clitics are ungrammatical whenever the subject is postverbal:
*El riva to fradèo
$\mathrm{He}=$ arrives your $=$ brother
'Your brother is coming'

(Padovano, Benincà 1994)

Moreover, with preverbal subjects the distribution of third person subject clitics is partly reminiscent of the French pattern in (20). Benincà and Poletto 2004 show that, with preverbal subjects, the clitic seems to be optional, see (23)a. However, if a dislocated object intervenes between the subject and the verb as in (23)b, then the clitic cannot be omitted. This means that the clitic is obligatory whenever the subject is left dislocated and that the optionality of (23)a is only apparent, as the presence of the clitic ultimately depends on the A/A' position of the subject.
a Mario (1) compra na casa
Mario (he=) buys a house
'Mario is going to buy a house'

b Mario, na casa, no *(1) la compra

Mario, a house, not (he=) it= will.buy

'Mario is not going to buy a house'

Hence, the facts in (22) and (23) show that the distinction between French and northern Italian dialects is less clear-cut than previously thought. More generally, the fact that doubling is subject to

\footnotetext{
2 The pattern in (20b) is in fact widely attested in informal French, e.g. Jean $i$-vient pas, which is reminiscent of the situation found in northern Italian dialects.
} 
many orthogonal factors casts some doubts on the hypothesis that the behaviour of subject clitics in Rhaeto-Romance, French, and Paduan is better explained by advocating a primitive distinction into classes.

Furthermore, if Rhaeto-Romance, French, and - to a lesser extent - Paduan subject "clitics" were not clitics (technically speaking), but weak pronouns, then one should expected them to behave like fully fledged weak subject pronouns such as Italian egli 'he', which, unlike its strong counterpart (lui 'he'), displays the canonical behaviour of weak elements, i.e. it cannot be used in isolation, cannot be focalised, coordinated ${ }^{3}$, etc.:
a. Egli/lui è stato visto.
he has been seen
b. Chi è stato visto? *Egli/lui
Who has been seen? He
c. è stato visto $*$ egli/lui
has been seen he
d. lui/*egli e Marco

However, egli, unlike subject clitics, can be separated from the verb by an adverb, see (25). If subject clitics of certain Romance languages end up falling into the same class of It. egli, then a contrast like (25) remains unaccounted for.
a. il $(* \ldots) \quad$ a mangé
b. Egli sicuramente ha mangiato
$\mathrm{He}$ certainly has eaten
'He certainly ate'

In conclusion, it seems to me that an analysis of Rhaeto-Romance and French subject "clitics" in terms of functional classes does not lead us to any improved model accounting for the observed cross-linguistic asymmetries. Since this holds for the comparison of genealogically related languages such as Italian, French, Rhaeto-Romance and northern Italian dialects, it is fair to conclude that the same - pessimistic - view can be easily extended to the comparison of data from different linguistic groups and families.

\section{Being doubled}

Although they cannot double another element, weak elements can be marginally doubled as shown in the following examples from modern Italian (Cardinaletti 1998: 138) and old Italian:
a. 'Gli
diede loro
uno schiaffo
to.him
he.gave to.them a slap

\footnotetext{
${ }^{3}$ Nowadays weak loro, egli are confined to a rather formal/written register. I have searched for cases of weak dative loro, egli in a corpus of spoken Italian. For instance, out of 570 occurrences of the word loro (including possessive, subject, oblique, and dative instances of the pronoun), I have found only four occurrences of weak loro: one in an informal conversation (but loro follows a word ending in $-a$, so it could be a misunderstood strong dative $a$ loro), another issue occurs in a homily ('and Jesus told them...'), while the other two occurrences are from TV/radio news. The data above support the impression that Italian speakers have a kind of passive competence of the usage of loro. In this sense, the syntax of weak loro - as well as the syntax of other weak forms such as egli 'he', cui 'of which/whom', etc. - is nothing but a relic of the proto-Romance case system (Loporcaro 2002: 54; Manzini \& Savoia 2014), which survives in old and, to a lesser extent, modern Italian as if it was part of a residual parallel grammar.
} 

b. Glie-lo consegnò loro la settimana scorsa to.him-it $=$ he.delivered to.them the last week
c. ?Ho deciso di dir-glie-lo loro domani
I.have decided to say=to.him=it to.them tomorrow

(27) E loro sì nne deono dare noi ${ }^{4}$

And they sì to.us= must give us

quello che lloro piacie

that that to.them pleases

'And they must give us what they like'

Doubling of a clitic by another clitic, by contrast, is rather unexpected, e.g.

(28) *Gli dovette portar-gli il libro

To.him=he.had.to bring=to.him the book

'He had to bring him the book'

However, there are dialects in which doubling configurations such as (28) are in fact attested in $18^{\text {th }}$ century Piedmontese (Parry 1998: 107-110). In compound tenses and restructuring environments, two instances of the object clitic occur, one in enclisis and the other in proclisis (see also Tortora 2014; 2015b). In present-day dialects, this pattern is quite rare: it is attested in three AIS $^{5}$ datapoints (Jaberg \& Jud 1928-1940), and in certain dialects of the Bormida valley such as Cairo Montenotte (Parry 2005: 179):
a. A 1 '
uma visct-le
$(\text { Cairese })^{6}$
$\mathrm{We}=\mathrm{him} / \mathrm{it}=$ have seen $=\mathrm{it} / \mathrm{him}$
"We saw him/it"
b. A 'm sun fò-me in fazing
$\mathrm{I}=$ to.myself $=$ am made=to.myself a cake
'I baked me a cake'
c. I l' an catò-le
they= it $=$ have bought $=\mathrm{it}$
"They bought it"

Elsewhere, the proclitic copy does not occur anymore, giving rise to a pattern of generalised enclisis with compound tenses, as shown in (30). As shown in (31), only the impersonal $s$ - is allowed to occur twice and, in contexts where it occurs once, as in (31)b, it is allowed to stand proclitic to the modal verb, cf. (31)b:
a. a $\quad 1$ peul di-lo
$(\mathrm{S}) \mathrm{he}=\mathrm{it}=\mathrm{can} \quad \mathrm{say}=\mathrm{it}$
b. a *(1) peul di-lo
$(\mathrm{S}) \mathrm{he}=\mathrm{it}=$ can $\quad \mathrm{say}=\mathrm{it}$
(18th century Piedm., Parry 1998: 108)
(present day Piedm.)
'(S)he can say'
a. a
s peul di-sse

\footnotetext{
${ }^{4}$ Libricciolo di Bene Bencivenni I, p. 305, rr. 20-21

${ }^{5}$ cf. AIS map. 1652: 122 Saint Marcel; 146 Montanaro; 147 Cavaglià.

${ }^{6}$ In certain dialects of Piedmont auxuliaries exhibit a non-referential proclitic $l$ - before auxiliary forms beginning with a vowel. Those in (29), however, are referential clitics as Cairese does not display clitics of auxiliary with these forms.
} 


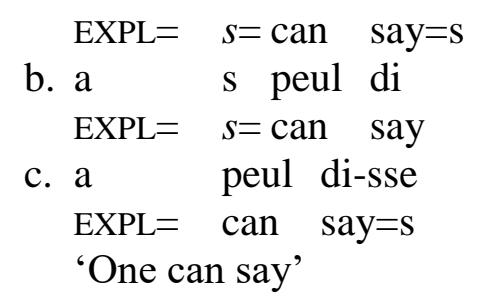

Similarly, in certain dialects of Piedmont (Parry 1997, Manzini \& Savoia 2005), Friuli (Benincà 1986 e 1994:122-23) and Valle d'Aosta (Roberts 1993), interrogative clauses exhibit two subject clitics, one in proclisis and the other in enclisis (as usual, enclitic and proclitic form are not identical, more on this in section 8):
(32) Còs o ra-lo fat? (Mondovì, CN, from Parry 1997: 93)
What he $=$ has=he done
'What did he do?'

As in the case of object clitics, this peculiar pattern of doubling is found in dialects undergoing a change in clitic placement as, according to Parry 1997: 94-95 these dialects are progressively losing the structure with inversion, which is replaced by an alternative construction in which T-to-C movement (and consequent enclisis) is blocked by inserting a complementiser after the whelement:

(33) Còsa ch' it veule?

What that you= want

'What do you want?'

In the light of the above data, one may conclude that 'doubling' patterns of the type clitic/clitic are in fact attested, in particular in an area of Italo-Romance subject to a radical and well documented change in clitic placement which, at first sight, does not hinge on the inner syntax of pronouns. Hence, it turns out that what we call 'doubling' is in fact a multifaceted phenomenon that, in the end, is not very telling about the internal structure of pronominal elements. Climbing will be further examined in the following section.

\section{Climbing}

Climbing is usually taken to be a defining property of clitics. For instance, Cardinaletti 2015 claims that "sentences with auxiliaries (e.g., active sentences with compound tenses and passive sentences) are contexts of obligatory clitic climbing: clitic pronouns do not attach to the past participle but occur in the high clitic position attached to the auxiliary". Weak pronouns like It. loro, conversely, are not forced to climb with the verb.

The above generalisation can have a series of possible formulations:

a. clitics must climb, weak cannot;

b. clitic must climb, weak can climb;

c. clitics can climb, weak cannot;

If (a) or (b) are assumed, then cases of (apparent) enclisis to the participle in compound tenses are to be analysed as instances of weak pronouns, as proposed by Cardinaletti 2015. However, in what follows I will show that none of the above generalisation holds: (c) is falsified by data from medieval Romance, see 6.1 ; while $(\mathrm{a} / \mathrm{b})$ are contradicted by data from several Romance varieties, see 6.2. 


\subsection{Preverbal weak pronouns in Romance}

In modern Italian, weak loro never occurs before the finite verb, while clitics normally stand proclitic to the inflected verb. In compound tenses, loro normally occurs after the past participle, but it can marginally occur before the participle in (35) (although some speakers say that the latter order is restricted to a very bureaucratic register) and, in restructuring contexts like (36), loro can climb above the infinitive.

(34) (*loro) diedi (loro) un bacio

to.them I.gave to.them a kiss

'I gave them a kiss'

(35) Ho ('loro) regalato (loro) il mio libro

I.have to.them given to.them the my book

'I gave them my book'

(36) a. Posso (loro) dire (loro) che...

I.can to.them say to.them that

'I can tell them that...'

b. Farò (loro) pulire (loro) la macchina

I.will.make to.them clean to.them the car

Old Italian, which exhibits a full paradigm of dative weak forms, allowed weak pronouns to occur between the auxiliary and the participle as in (37) and, unlike modern Italian, before the inflected verb in sentences without T-to-C movement as in (38) (Cardinaletti 2010: 418-424, 427429):

(37) i quali d. avea loro lasciati Baldovino $^{7}$

which money had to.them lent B.

'money that Baldovino had lent to them'

(38) a. Vertute $[\ldots]$ lui obedisce e lui acquista onore ${ }^{8}$ Virtue to.him obeys and to.him acquires honor

'virtue obeys him, and so honors him,'

b. quello che lloro piacie $^{9}$

that that to.them pleases

'what pleases them'

In conclusion, the above data show that, although weak elements climb less readily than clitic pronouns and, diachronically, tend to climb less and less, nonetheless they are not necessarily bound to a postverbal position in the low IP area.

\subsection{Generalised enclisis}

\footnotetext{
${ }^{7}$ [1278], Libro d'amministrazione dell'eredità di Baldovino Iacopi Riccomanni p. 438, vv. 20-21 (La prosa italiana delle origini: I, Testi toscani di carattere pratico, a cura di Arrigo Castellani, Bologna, Pàtron, 1982)

${ }^{8}$ Dante, Rime, 49 CVI

${ }^{9}$ Libricciolo di Bene Bencivenni I, p. 305, rr 20-21
} 
Enclisis in compound tenses is attested in several Romance areas: Franco-Provençal (Chenal 1986), Piedmontese (Parry 2005 a.o.), Dolomitic Ladin (Rasom 2008), Abruzzese (Benincà \& Pescarini 2015), Romanian (limited to the accusative feminine clitic $o$ ):

(39) L' an tot portà-lèi vià. (Chenal 1986:340)

They $=$ have everything carried=to.him away

'They have taken everything away from him.'

(40) a. I an rangiò-la.

(Cairo Montenotte, Parry 2005)

They= have fixed=it.F

'They fixed it.'

(41) a. 'ajə ddza mən'jetəməlu (San Valentino in Abruzzo cit;

I.have already eaten=to.me=it Benincà \& Pescarini 2015)

b. 'ajə ddza mə lu mən'jetə

I.have already to.me $=\mathrm{it}=$ eaten

'I have already eaten it'

(42) a. Am mâncat-o

I.have eaten-it.F

'I ate it'

b. aş mâncat-o

I.would eat- it.F

'I would eat it'

As for Romanian and Italian dialects, notice that enclisis is compatible with doubling. Then, if doubling is a defining property of clitics (see above), one cannot claim that also climbing is.

(43)
Am vazut-o pe ea.
(Romanian)
I.have seen-her DOM her
'I have seen her.'

In my opinion, the lack of climbing can be better analysed in terms of external (namely, clausal) factors. In subsection 4 I have already argued - following previous works by Parry 1997, 1998, 2005 - that enclisis in northwestern Italian dialects results from a change affecting the climbing mechanism (see Tortora 2015), rather than a change in the status of the pronoun. In fact, while it is reasonable to think that weak pronouns can evolve into clitics (Egerland 2005, 2010), the opposite change is rather unlikely. Conversely, if Piedmontese and Valdôtaine enclitics are analysed as weak, we are forced to conclude, given the historical reconstruction provided in section 4 , that in these languages proclitic elements turned into weak forms.

Tortora 2015a argues for an alternative analysis of Piedmontese. In a nutshell, climbing is blocked as compound tenses are reanalysed as a kind of biclausal structure. The hypothesis that, in previous stages of Romance, compound tenses were 'less monoclausal' than nowadays may then account for data from early Italian (Poletto 2014), in which enclisis to the past participle is attested in compound tenses under ellipsis:

(44) a. m' ha con un bastone tutto rotto e dettami la maggior me $=$ has with a cudgel all broken and said=to.me the greatest villania che mai si dicesse a niuna cattiva femina ${ }^{10}$

\footnotetext{
${ }^{10}$ Boccaccio, Decam.
} 


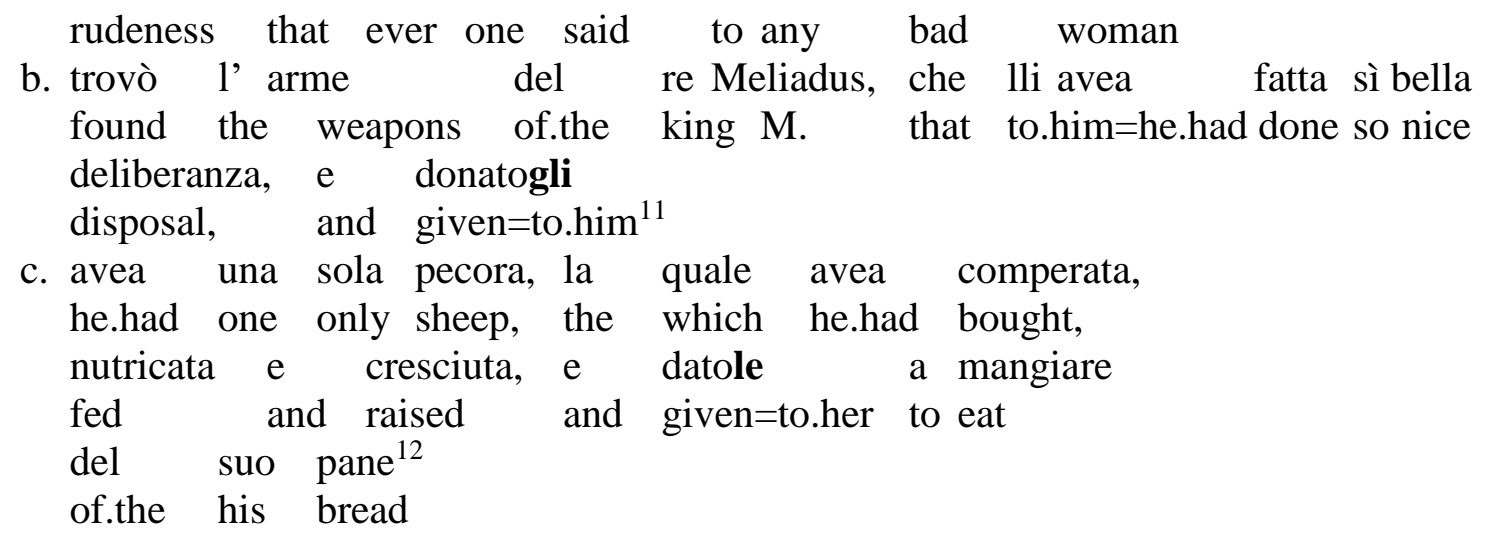

In modern Italian, sentences like those illustrated in (35) are ungrammatical as clitics must climb and climbing is allowed if and only if the same (kind of) argument is pronominalized in both conjoints:

(45) a. ${ }^{*} \mathbf{m i}$ ha
me= has scidato e pichiato-mi.
b. $\mathbf{m i}$ ha sgridato e pichiato.
$\mathrm{me}=$ has scolded and hit
' $\mathrm{He} /$ she scolded and hit me'

The contrast between old and modern Italian is arguably due to the syntactic structure of sentences featuring compound tenses in concert with the conditions ruling clitic climbing, i.e. external, clausal factors. Conversely, an analysis in terms of pronominal classes would not offer any promising account of the facts illustrated in (44)-(45) or improve our understanding of clitic placement in the languages exemplified in (39)-(42) (more on this in the next section).

\section{Split clusters}

In many Romance languages, clitics form tight clusters with a rigid order. However, sometimes clitics can co-occur without forming a cluster. For instance, in some Franco-Provençal dialects dative and accusative clitics are not adjacent as the dative clitic climbs, while the accusative one remains enclitic to the past participle:

(46) a. T' an- të prèdzà-nen?

to.you $=$ have $=$ they spoken $=$ of.it?

'Did they speak of it to you?'

b. T' an-të deut-lo?

to.you= have=they said=it?

'Did they say it to you?'

Arguably, this state of affairs is a consequence of the climbing mechanism. On the basis of data from different Italian dialects, Rasom 2008 and Tortora 2014a/b show that changes in clitic placement do not affect all clitic forms at the same time. As a consequence, certain dialects may exhibit patterns of 'selective' climbing (the terminology is mine) as some clitics must/can climb, while others must attach to the past participle, thus resulting in a split configuration.

\footnotetext{
${ }^{11}$ Novellino, 63

12 Ottimo, p. 304
} 
Similar phenomena occur in restructuring environments, where clitic sequences can be split even in languages in which clitics normally form tight clusters. Old Italian displays a bunch of examples, in (47), but a similar pattern is allowed in modern Italian as well, see (48) (Pescarini 2014):

(47) a. Ma la cosa incredibile mi fece $^{13}$

But the incredible thing me $=$ made

indur-lo ad ovra ch'a me stesso pesa

induce $=$ him to work that to my self weighs

'But your plight, being incredible, made me goad him to this deed that weighs on me'

b. se 'n tal maniera mi dovete dar-lo. ${ }^{14}$

if in such way to.me $=$ you.have.to give $=$ it

'if you have to give it to me in this way'

(48) a. si può portar-lo domani ${ }^{15}$

one $=$ can take $=$ it tomorrow

'we can take it tomorrow'

b. ${ }^{\%} \mathbf{m i}$ ha dovuto portar-ci un'amica ${ }^{16}$

$\mathrm{me}=$ has had take $=$ there a friend. $\mathrm{F}$

'A friend of mine had to take me there'

c. ${ }^{\%}$ ' ha dovuto portar-mi un'amica

there $=$ has had take $=$ me a friend.F

'A friend of mine had to take me there'

The data above show that 'forming a tight cluster' is not per se a defining property of clitic combinations as, whenever they are not subject to mandatory placement conditions (as in restructuring contexts), they are free to occur separately.

In my opinion, the data in (47)-(48), coupled with the biclausal analysis of compound tenses offered by Tortora 2015a, may shed light on the pattern in (46) by elaborating a finer theory of clitic climbing accounting for all the above data coming from restructuring and non-restructuring environments. Conversely, if we pursue an analysis of (46) in terms of pronominal classes (by claiming that the lower pronoun is weak and not clitic), we end up missing the relation holding between the puzzling behaviour of (46) and the far less exceptional patterns in (47)-(48), unless one claims that the pronouns in (47)-(48) are weak as well.

\section{Proclisis/enclisis asymmetries}

Laenzlinger 1993, 1994, Ordóñez and Repetti 2006, 2014; Cardinaletti 2015a, 2015b have argued that some puzzling morphophonological alternations between proclitics and enclitics can be accounted for if certain enclitic pronouns are analysed as weak elements.

In many languages, enclitic pronouns tend to be 'heavier' than proclitics even in absence of stress shift phenomena (see also Renzi and Vanelli 1983 on subject clitics). Several asymmetries can be accounted for under trivial phonological accounts, but not all alternations lend themselves to

\footnotetext{
${ }^{13}$ Dante, Inf. 13: 50-51

${ }^{14}$ Amico di Dante, Rime, Son. 44

${ }^{15}$ Notice that the impersonal si follows the accusative clitic, e.g. lo si, while the reflexive si exhibits the mirror order. Furthermore, it is worth noting that the impersonal clitic must climb in restructuring construction, this is why the counterpart of (26a) with the opposite order of clitics, e.g. *lo può portarsi domani, is ungrammatical. Notice that this is orthogonal to the issue of separability.

${ }^{16}$ Retrieved via Google on 30.10.12.
} 
a phonological analysis (Ordóñez and Repetti 2006, 2014; see Manzini \& Savoia 2005 for further data).

For instance, in modern French 1/2p enclitics are identical to strong forms:

(49) a. Il me le donne

He to.me it gives

'He gives it to me'

b. Donne-le-moi!

Give-it-to.me

'Give it to me!'

Laenzlinger (1993), from which the below data are taken, argues that the me/moi alternation is syntactic in nature and that moi is in fact a weak pronoun. He discards the hypothesis that the me/moi alternation may be due to the assignment of stress to the word-final syllable (Foulet 1924). Although it might be a possible diachronic explanation, the phonological account cannot hold synchronically, as the same alternation is observed in non-standard varieties displaying the opposite order of clitics, e.g., subst. Fr. donne=moi=le.

(50) a. Donne-le-moi!

b. Donne-moi-le!

c. Donne-me-le!

d. *Donne-le-me!

'give it to me'

However, if we pursue an account along the lines of Laenzlinger's, we should extend the same analysis to third person dative clitics insofar as the original dative clitic $l i$ ('to him/her' > Lat. ILLI) has been replaced, either in enclisis or in proclisis, by the oblique form lui:
a. Et il li dit: And he to.him/her= says 'and he says to him/her:'
b. Et il lui dit:
And he to.him/her says
'and he says to him/her:'
(Old French)
(Modern French)

Noticeably, the form lui was attested in old French, but it functioned as a strong pronoun, as it also does in modern French. Following Laenzlinger's view, the change in (41) could be eventually viewed as the substitution of a clitic element with a weak element. Moreover, we can even wonder whether a similar change had happened with the plural clitic, which has been lor (<ILLORUM) since the earliest attestations instead of the expected *lis $(<$ ILLIS). Hence, if morphological evidence leads to conclude that moi in (50) is a weak pronoun, for the same reason one would conclude that French dative clitics lui/lor are in fact weak, both in enclisis and in proclisis. The point is that, in the end, no empirical or theoretical gain results from this move.

In general, such analyses rest on theories envisaging a direct mapping from syntax to morphology. In this view, weak pronouns are expected to exhibit a richer morphology insofar as they correspond to a larger chunk of structure (Manzini \& Savoia 2004 a.o.). However, clitics often have a rather complex morphology. In particular, third person accusative pronouns differ from other clitics in having a composite form featuring an inflectional ending. Furthermore, several Romance languages exhibit cases of 'compound' clitic forms, i.e. clitics expressed by a combination of two clitic formatives. In many Veneto dialects, for instance, the genitive/partitive clitic is formed by a combination of the locative clitic ghe [ge] and the partitive element $n e$ (5a). The composite structure 
of the partitive is synchronically evident, as in several Veneto varieties the former item (ghe) disappears once the partitive is combined with a dative or locative clitic (Benincà 1994), see (52)b:
a. ghene $=$ magno do (Pad.)
of.it/them = I.eat two
'I eat two of them'
b. te $=\quad(*$ ghe $)$ ne $=$ porto do $(\mathrm{Pad}$.
to.you of.it/them I.bring two
'I bring you two of them'

Hence, clitics such as ghene feature two morphemes, but their internal structure cannot be considered akin to the one of third person clitics such as lo, la. In diachrony, ghene is due to the combination of two independent particles, while a clitic like $l o$ is the reflex of a single Latin form with the morphology of a nominal element.

Lastly, there are more complicated cases in which clitic items have an internal structure which seems due to the combination of different clitics and agreement markers. As shown in (53)a, the Gascon clitic lousi 'to them.M' can be decomposed into an accusative form lous 'them' plus the oblique marker $i$ (identical to the so-called locative clitic corresponding to the Venetan ghe in (52)). In turn, the accusative clitic lous is formed by several formatives ( $l--o u--s)$. Analogously, the Catalan dialect spoken in Barcelona (Bonet 1991) exhibits a similar compound plural dative form due to the combination of the accusative clitic elz $(e l+$ plural $-z)$ with $i$ :
lou 'it/him'
lous 'them'
i 'there'
lousi 'to them'
a. Gascon (Rohlfs 1970):
b. Barceloní Catalan (Bonet 1991)
(e)l 'it/him'
(e) $l z \quad$ 'them'
hi /i/ 'there'
(e)lzi 'to them' (sometimes written elz'hi)

Notice that in the latter case there is evidence supporting that the morphological boundary between $(e) l z$ and $-i$ is synchronically active. In fact, when the dative clitic combines with the partitive clitic (a) $n$, the latter occurs between the two formatives of the dative clitic, namely: elz $+n$ $+i$ (Bonet 1991):

(35) a. Als nens lzi donare pomes demà.
To.the kids to.them= I.will.give apples tomorrow
b. De pomes en donare als nens demà
Of apples of.them= I.will.give to.the kids tomorrow
c. De pomes als nens lzni $(*$ lzin) $\quad$ donare demà
Of apples to.the kids to.them=of.them= I.will.give tomorrow
'Tomorrow I will give apples to the kids'

This shows that certain clitic forms have a composite structure due to the combination of several clitic items and that such compound structures have not undergone reanalysis. In fact, the morphological boundary between the two is still active as they undergo partial dropping (as in the case of Venetan ghene) or allow the insertion of intervening clitic material as in the case of Barceloní.

In conclusion, the data above show that morphological complexity cannot be taken as a reliable parameter to distinguish clitic from weak pronouns and, more generally, to argue for the existence of classes of functional elements. 


\section{Interpolation}

Benincà \& Cinque 1993 elaborate on a series of asymmetries between proclitics and enciltics, leading to the conclusion that the latter are 'closer' to the verbal host than the former. Among the various diagnostics, the generalisation is supported by interpolation phenomena, i.e. occurrence of adverbs or other constituents between a clitic and its host. With proclitics, interpolation is attested in a number of present-day languages such as western Ibero-Romance (Uriagereka 1995) and in several Italo-Romance dialects: Triestino (Benincà 1997: 129; Paoli 2007), Cosentino (Ledgeway and Lombardi 2005), the dialect spoken in Antrodoco (Scorretti 2012) and other (upper) southern Italian varieties (see references in Ledgeway and Lombardi 2005).
a. Si sempre lava
Self= always he.washes
'he always washes himself'
b. el me sempre dizi
$\mathrm{He}=$ to.me $=$ always says
'He always speaks to me'
(Triestino, Benincà 1997: 129)

(Cosentino, Ledgeway \& Lombardi 2005)

Interpolation between proclitics and the verb was marginally allowed in old Italian and old French, while in old Spanish and Portuguese (but not in Catalan), interpolation was more productive as several constituents of any kind could be interpolated.

With enclitics, conversely, Benincà and Cinque 1993 concluded that interpolation was not attested. They therefore argued that any theory of clitic placement must account for the fact that proclitics can be separated from the verb, while enclitics cannot.

The generalisation, however, was later contradicted by data from some dialects spoken at the Piedmont/Lombardy border, in which enclitics can be separated from the verb by aspectual adverbs (Tortora 2002, 2015):
a. I porti mi-lla.
mija 'not'
$\mathrm{I}=$ bring $(1 \mathrm{sg}) \mathrm{NEG}-\mathrm{it}$
'I'm not bringing it.'
b. I vangumma già-nni da dü agni.
$\mathrm{We}=$ see already-us of two years
già 'already'
'We've already been seeing each other for two years.'
c. I vônghi piö-llu.
piö 'anymore'
$\mathrm{I}=\operatorname{see}(1 \mathrm{sg})$ anymore-him
'I don't see him anymore.'

It is worth recalling that Piedmontese dialects in general exhibit enclisis is compound tenses and some eastern Piedmontese, including Boromanerese, have generalised enclisis in all finite clauses. In section 5 and 6 I argued, following Tortora 2015a/b that enclitic placement is better understood in terms of an external - namely, clausal - phenomenon which, in principle, might be extended to the pattern in (55). By contrast, Cardinaletti 2015 entertains the hypothesis that the pronouns in (55) are weak elements occurring in the same position of Italian loro (in fact, Italian loro can follow certain aspectual adverbs, while enclitics are adjacent to the verb).

However, there is no principled reason why interpolation with enclitics is recognised as a clue of weak pronouns, while interpolation with proclitics is not. As a matter of fact, Benincà and Cinque argued that the structural 'distance' between the host and enclitics is smaller than that occurring between the host and proclitics. Then, given (55), one is expected to conclude that Borgomanerese enclitics have the same status of proclitics in western Ibero-Romance, southern Italo-Romance, and 
Triestino. Crucially, if a weak analysis is advanced for the former, the same explanation should hold for the latter as well.

\section{Complement of $P$}

Cardinaletti \& Starke 1996: 24 notice that one of the properties distinguishing Romance clitics from Germanic weak pronouns is the possibility of occurring in the complement position of prepositional phrases:

(56) a. Je pars avec *le/lui

$\mathrm{I}=$ leave with him

'I leave with him'

b. Ich kann ohne es nicht leben

I can without it not live

'I cannot live without it'

Clitics pronouns can in fact be the complement of prepositions, but then they must climb to the inflected verb. Again, the ungrammaticality of clitics under prepositions can be seen as a side effect of the climbing requirement.
a. Va-lle dietro $(* 1 e)$ !
Go=to.her beside
'Follow her'
b. $\mathrm{Ci}$ sei seduto sopra (*ci).
There $=$ you.are sit on
'you are sitting on it'
c. $\mathrm{Mi}$ era seduto accanto (*mi).
To.me $=$ he/she.was sit near
'He/she was sitting near me'

As for the weak loro, one may expect loro not to climb outside the prepositional phrase (like Germ. es). However, loro must occur in the usual postparticipial position even if it originates as the argument of prepositions selecting for a dative complement. In this respect, weak It. loro does not pattern like Germ. es, but - mutatis mutandis - like a clitic.
a. $\mathrm{Si}$ era seduto loro vicino
Him/herself $=$ he/she.was sit to.them near 'He/she was sitting near them'
b. $\mathrm{Si}$ era seduto vicino *loro / a loro
$\mathrm{Him} /$ herself $=$ he/she.was sit near to.them / to them
'He/she was sitting near them'

Furthermore, certain Italian vernaculars show cases of clitics following the preposition. This is attested in a bunch of examples from old Italian in which the dative clitic gli 'to him' follows the lexical preposition, see (59). Cardinaletti (2015b: §7.1) proposes that gli in (59) is a weak element. However, it is worth recalling that old Italian weak pronouns are identical to strong pronouns (e.g. $l u i=$ weak 'to him', strong 'him', Cardinaletti 2010), while gli is a fully-fledged clitic. 
(59) a. essa incontro-gli da tre gradi discese ${ }^{17}$

She towards-him from three steps took.down

'She took three steps down towards him'

b. e l' altro dietro-gli ${ }^{18}$

and the other behind=him

'and the other after him'

c. e 'l maestro Dino allato-gli ${ }^{19}$

and the mister D. along=him

Instances of enclitics to prepositions are found in present-day dialects such as the one spoken in Cairo Montenotte, see (60) (Parry 2005: 179).

(60) a. S' u n' ièra chila dedré-me, mi i perdiva

If she $=$ not $=$ was she behind $=$ me, I them $=$ lose

If she had not been behind me, I would have lost them'

b. u iè ina sc-trò própi lì dedré-te

$\mathrm{SCL}=$ is a street just there behind=you

'there is a street just behind you'

It is worth noting that Cairese in one of the aforementioned Piedmontese dialects showing enclisis in finite clauses with compound tenses. In particular, Cairese clitics are doubled, i.e. the pronoun occurs twice, both in proclisis and in enclisis (I repeat below the relevant example):
a. A l' uma visct-le (Cairese)
$\mathrm{We}=\mathrm{him} / \mathrm{it}=$ have seen $=\mathrm{it} / \mathrm{him}$
"We saw him/it"
$\mathrm{I}=$ to.myself $=$ am made $=$ to. myself a cake
'I baked me a cake'
b. A 'm sun fò-me in fazing
c. I l' an catò-le
they $=\mathrm{it}=$ have bought=it
'They bought it"

Cardinaletti 2015a argue that both (60) and (61) are evidence for weak pronouns as they occur in dialects with generalised enclisis. However, enclisis to certain prepositions is attested in several other varieties that do not display enclisis in finite clauses (Salvioni 1903; Vedovato and Berizzi 2011; Cuzzolin 2015):
(62) no sten ndar drio-ghe (Fossalta di Piave)
not we.stay to.go behind-to.him/her
'Let us not follow him/her'

In conclusion, the data discussed so far corroborate the idea that being the complement of $\mathrm{P}$ is not a solid diagnostic distinguishing between pronominal classes. In fact, alleged weak pronouns such as Italian loro are obligatorily extracted from PPs, while enclisis to prepositions is allowed in a few Romance dialects.

\footnotetext{
${ }^{17}$ Boccaccio, Decameron, II.5: p. 100.

${ }^{18}$ Sacchetti, Franco [1400], Trecentonovelle (Il) (a cura di Vincenzo Pernicone, Firenze, Sansoni, 1946.), p. 245 , v. 29.

${ }^{19}$ Ibidem, p. 199 , v. 6.
} 


\section{Conclusions}

In some Romance varieties, clitics have an unexpected, 'non-canonical' behaviour: they may be stressed, do not always climb to the auxiliary in compound tenses, may be separated from the verb by certain adverbs, etc.

Laenzlinger 1993, 1994; Ordóñez and Repetti 2006, 2014; Cardinaletti 2015 among others have argued that the aforementioned non-canonical clitics are in fact weak elements in the technical sense of Cardinaletti 1991, 1994, 1998; Cardinaletti \& Starke 1996, 1999.

However, many tests that are normally used for the definition of classes do not hold crosslinguistically, while other diagnostics are often contradictory.

From a theoretical point of view, this means that there is no clear evidence for a principled distinction between classes and, in particular, there is no conclusive evidence supporting the idea that the distribution, shape, and further characteristics of pronouns depend on their internal make up, i.e. their inner syntax. Although (2) provides an elegant and appealing analysis of several puzzles, the overall scenario shows that so called classes are arguably to be defined as clusters of properties originating from rules and constraints taking place at the clausal level.

\section{References}

Benincà, P. (1980) "Nomi senza articolo," Rivista di grammatica generativa, 5, 51-63.

Benincà, Paola (1983). 'Il clitico a nel dialetto padovano' in Benincà et al., Scritti linguistici in onore di G. B. Pellegrini. Pisa: Pacini, 25-35. (Reprinted in Benincà 1994)

Benincà, Paola (1983-4). 'Un'ipotesi sulla sintassi delle lingue romanze medievali' Quaderni Patavini di Linguistica 4: 3-19.

Benincà, Paola (1986). 'Punti di sintassi comparata dei dialetti italiani settentrionali', in G. Holtus and K. Ringger (eds.), Raetia antiqua et moderna. W. Th. Elwert zum 8O. Tübingen: Geburtstag, 457-79 (Republished in Benincà 1994)

Benincà, Paola (1988). 'L'ordine degli elementi della frase e le costruzioni marcate', in L. Renzi, Grande grammatica italiana di consultazione. Bologna: Il Mulino, 115-192.

Benincà, Paola (1994). La variazione sintattica. Bologna: Il Mulino.

Benincà, Paola (1995). 'Complement clitics in Medieval Romance: the Tobler-Mussafia Law'. Clause Structure and Language Change, ed. by A. Battye and I. Roberts, 325-344. New York and Oxford: Oxford Universiry Press.

Benincà, Paola (2006). 'A detailed map of the Left Periphery in Medieval Romance', in R. Zanuttini, H. Campos, E. Herburger, and P. Portner (eds.), Negation, Tense, and Clausal Architecture: Crosslinguistic Investigations, Washington: Georgetown University Press, 53-86.

Benincà, Paola, and Cinque, Guglielmo (1993). 'Su alcune differenze tra enclisi e proclisi' in Omaggio a Gianfranco Folena, ed. by Michele A. Cortelazzo, Erasmo Leso, Pier Vincenzo Mengaldo, Gianfelice Peron, and Lorenzo Renzi. Padova: Editoriale Programma, 2313-2326.

Benincà, Paola and Diego Pescarini (2015). 'Clitic placement in the dialect of S. Valentino in Abruzzo citeriore'. Archivio Glottologico Italiano, 37-65.

Benincà, Paola \& Cecilia Poletto (2004). Topic, focus and V2: defining the CP sublayers. In Rizzi, L. (ed.), The Structure of CP and IP: The Cartography of Syntactic Structures, Volume 2. Oxford: Oxford University Press. $52-75$.

Bonet, Eulalia (1991). Morphology after syntax: Pronominal clitics in Romance. MIT: Doctoral dissertation.

Cardinaletti, Anna (1991). 'On pronoun dative movement. The Italian dative loro' Probus 3, 127153. 
Cardinaletti, Anna (1994). 'On the internal structure of pronominal DPs' The Linguistic Review 11: 195-219.

Cardinaletti, Anna (1998). On the deficient/strong opposition in possessive systems in A. Alexiadou \& Ch. Wilder (eds.), Possessors, Predicates, and Movement in the Determiner Phrase. Amsterdam: Benjamins, 17-53.

Cardinaletti, Anna (2010). 'Il pronome personale obliquo' in G. Salvi and L. Renzi, Grammatica dell'italiano antico, vol. I Bologna: il Mulino, 414-450

Cardinaletti, Anna (2015a). 'Cases of apparent enclisis on past participles in Romance varieties' Isogloss 1.2: 179-197.

Cardinaletti, Anna (2015b). 'Syntactic Effects of Cliticization' in T. Kiss and A. Alexiadou, Syntax. Theories and Analyses, Vol. I. Berlin: Mouton de Guyter, 595-653.

Cardinaletti, Anna and Starke, Michel (1996). 'Deficient pronouns: A view from Germanic'. In Hoskuldur Thrainsson (Ed.), Studies in Comparative Germanic Syntax II. Dordrecht: Kluwer, 21-65.

Cardinaletti, Anna and Starke, Michel (1999). 'The typology of structural deficiency: a case study of the three classes of pronouns' in Clitics in the Languages of Europe, ed. by Henk van Riemsdijk. Berlin and New York: Mouton de Gruyter, 145-233.

Chenal, Aimé (1986). Le franco-provençal valdôtain. Aoste: Musumeci.

Cuzzolin, Pierluigi (2015). 'Vae drioghe, mi! Sull'interpretazione del clitico ghe in alcune varietà di Veneto' in Mariagrazia Busà and Sara Gesuato, Lingue e contesti. Studi in onore di Alberto M. Mioni. Padova: Cleup, 573-582.

Chenal, Aimé. 1986. Le franco-provençal valdôtain. Aoste: Musumeci.

Dèchaine R.-M. \& Wiltschko, M. (2002). 'Decomposing pronouns' Linguistic Inquiry 33: 409-422.

Dragomirescu, Adina (2013). 'Complex predicates' in Gabriela Panã Dindelegan, The grammar of Romanian. Oxford: Oxford University Press.

Egerland, Verner (2005). 'Diachronic change and pronoun status: Italian dative 'loro'. Linguistics, 43, 1105-1130.

Egerland, Verner (2010). 'I pronomi lo' e 'ro nel toscano dei primi secoli' L'Italia Dialettale, 71, 111-145.

Egerland, Verner (2013). 'On the grammar of kinship: Possessive enclisis in Italian dialects' In Jeppesen Kragh, K. \& Lindschouw, J., Deixis and Pronouns. Amsterdam: Benjamins, 69-83.

Foulet, Lucien (1919). Petite syntaxe de l'ancien francais. Paris: Champion.

Foulet, Lucien (1924). 'L'accent tonique et l'ordre des mots : formes faibles du pronom personnel après le verbe', Romania 50: 54-93.

Foulet, Lucien (1935). 'L'extension de la forme oblique du pronom personnel en ancien français', Romania 61: 257-315, 401-63

Giusti, Giuliana (2010). 'I possessivi', in Salvi, G. and L. Renzi, Grammatica dell'italiano antico. Bologna: Il Mulino, 359-375.

Holmberg, Anders (1986). Word order and syntactic features in the Scandinavian languages and English. Unpublished doctoral dissertation, Department of General Linguistics, University of Stockholm.

Holmberg, Anders (1991). 'The distribution of Scandinavian weak pronouns' in Clitics and their Hosts, ed. by Henk van Riemsdijk and Luigi Rizzi. Geneva and Tilburg: ESF-Eurotype, 155174.

Jaberg, Karl \& Jakob Jud (1928-1940). Sprach- und Sachatlas Italiens und der Südschweiz, Vol.18, Zofingen, Bern. Digital version by Graziano Tisato: http://www3.pd.istc.cnr.it/navigais-web/

Kayne, Richard (1975). French syntax: the transformational cycle. Cambridge (Mass.): MIT Press.

Kayne, Richard (1983). 'Chains, Categories External to S and French Complex Inversion' Natural Language and Linguistic Theory 1: 107-139.

Laenzlinger, Christopher (1993). 'A syntactic view of Romance pronominal sequences' Probus, 5.3: $242-270$. 
Laenzlinger, Christopher (1994). 'Enclitic clustering: The case of French positive imperatives' Rivista di Grammatica Generativa, 19: 71-104.

Ledgeway, Adam and Linda Lombardi (2005). 'Verb Movement, Adverbs and Clitic Positions in Romance', Probus 17:79-113.

Loporcaro, Michele (2002). 'Il pronome loro nell'Italia centro-meridionale e la storia del sistema pronominale romanzo', Vox Romanica 61, 48-116.

Rivero, María Luisa (1986). 'Parameters in the Typology of Clitics in Romance and Old Spanish' Language, 62(4):774-807, 1986.

Rivero, María Luisa \& José Lema (1991). 'Types of Verbal Movement in Old Spanish: Modals, Futures and Perfects' Probus 3.3: 237-278

Longobardi, G 1994, 'Reference and proper names: a theory of N-movement in syntax and logical form' Linguistic Inquiry, pp. 609-665.

Manzini, Maria Rita (2014). 'Grammatical categories: Strong and weak pronouns in Romance'. Lingua, vol. 150, pp. 171-201.

Manzini, Maria Rita, and Savoia, Leonardo (2004). 'Clitics: Cooccurrence and mutual exclusion patterns' in Luigi Rizzi (ed.), The structure of CP and IP. Oxford: Oxford University Press, 21150.

Manzini, Maria Rita, and Savoia, Leonardo (2005). I dialetti italiani e romance. Morfosintassi generativa. Alessandria: Edizioni Dell'Orso.

Manzini, Maria Rita, and Savoia, Leonardo (2009). 'Morphology dissolves into syntax: Infixation and Doubling in Romance languages' Annali Online di Ferrara-Lettere 1: 1-28.

Manzini, Maria Rita; Savoia, Leonardo Maria (2014). 'From Latin to Romance: case loss and preservation in pronominal systems' Probus, vol. 26, 2, pp. 217-248.

Ordóñez, Francisco and Lori Repetti (2006) "Stressed Enclitics?" New Analyses on Romance Linguistics: Volume II: Phonetics, Phonology and Dialectology (Selected Papers from the 35th LSRL 35) Jean-Pierre Montreuil, ed. Amsterdam \& Philadelphia: John Benjamins, 167-181.

Ordóñez, Francisco and Lori Repetti (2014) "On the morphological restriction of hosting clitics in Italian and Sardinian dialects" Italia dialettale 75: 173-199.

Palasis, Katerina (2015). 'Subject clitics and preverbal negation in European French: Variation, acquisition, diatopy and diachrony' Lingua 161: 125-143.

Paoli, Sandra (2007). 'Interpolation structures and clitics in Triestino', in Bentley, Delia and Ledgeway, Adam (Eds.), Sui dialetti italoromanzi: saggi in onore di Nigel B. Vincent, The Italianist 27, Special Supplement 1: 184-199.

Parry, Mair (1993). 'Subject clitics in Piedmontese: a Diachronic Perspective', Vox Romanica 52: 96-116.

Parry, Mair (1997). 'Preverbal negation and clitic ordering, with particular reference to a group of North-West Italian dialects', Zeitschrift für Romanische Philologie, 113.2: 243-70.

Parry, Mair (1998).

Parry, Mair (2005). Parluma 'd Coiri. Sociolinguistica e grammatical del dialetto di Cairo Montenotte. Savona: Editrice Liguria.

Pescarini, Diego (2014). 'Prosodic restructuring and morphological opacity. The evolution of ItaloRomance clitic clusters' in: Ledgeway A, Benincà P, Vincent N. (eds.) Diachrony and Dialects: Grammatical Change in the Dialects of Italy. New York - Oxford: Oxford University Press

Poletto, Cecilia (2000). The Higher Functional Field. Evidence from Northern Italian Dialects. Oxford - New York: Oxford University Press.

Poletto, Cecilia. 2002. The left periphery of V2 Rhaetoromance dialects: a new view on V2 and V3. In Syntactic Microvariation, ed. by Sjef Barbiers, Leonie Cornips, and Susanne van der Kleij, 214-242. Amsterdam: Meertens Institut (https://www.meertens.knaw.n1/books/synmic/)

Rasom, Sabrina (2008). Lazy concord in the Central Ladin feminine plural DP: A case study on the interaction between morphosyntax and semantics. Doctoral dissertation, University of Padua. Available at http://paduaresearch.cab.unipd.it/268/1/tesiSabrinaRasom.pdf. 
Renzi, Lorenzo \& Laura Vanelli (1983). 'I pronomi soggetto in alcune varietà romanze', In Paola Benincà et al. (eds.), Scritti in onore di G.B. Pellegrini, Pisa, Pacini, 120-145.

Repetti, Lori (2016). 'The phonology of postverbal pronouns in Romance languages' in Romance Linguistics 2013: Selected papers from the 43rd Linguistic Symposium on Romance Languages (LSRL), New York, 17-19 April, 2013, Edited by Christina Tortora, Marcel den Dikken, Ignacio L. Montoya and Teresa O'Neill. Amsterdam: Benjamins, 361-378.

Rivero, M. L. 1991. 'Clitic and NP Climbing in Old Spanish'. Current Studies in Spanish Linguistics, ed. by H. Campos and F. Martínez-Gil, 241-282. Washington, D. C.: Georgetown University Press.

Rivero, M. L. 1997. 'On two locations for complement clitic pronouns: Serbo-Croatian, Bulgarian and Old Spanish'. Parameters of Morphosyntactic Change, ed. by A. van Kemenade and N. Vincent, 170-206. Cambridge: Cambridge University Press.

Roberts, Ian (1993). 'The nature of subject clitics in Franco-Provençal Valdôtain' in A. Belletti (ed.), Syntactic Theory and the Dialects of Italy. Turin: Rosenberg \& Sellier, 319-353.

Rohlfs, Gerhard (1966). Grammatica storica della lingua italiana e dei suoi dialetti. Torino: Einaudi.

Rohlfs, Gerhard (1970). Le gascon. Tübingen: Niemeyer.

Salvioni, Carlo (1903). 'Del pronome enclitico oggetto suffisso ad altri elementi che non sieno la voce verbale' Rendiconti del reale istituto lombardo di scienze e lettere 36: 1012-1021.

Scorretti, Mauro (2012). Il dialetto di Antrodoco. Pescara: Fondazione Ernesto Gianmarco.

Starke, Michal (2009). 'Nordlyd 36.1, ed. Peter Svenonius, Gillian Ramchand, Michal Starke, and Knut Tarald Taraldsen, pp. 1-6 ' Nordlyd 36.1: 1-6.

Tortora, Christina (2002). 'Romance enclisis, prepositions, and aspect' Natural Language and Linguistic Theory 20: 725-758.

Tortora, Christina (2014a). 'Patterns of variation and diachronic change in Piedmontese object clitic syntax' in P. Benincà, A. Ledgeway, \& N. Vincent (eds.) Diachrony and Dialects. Oxford: Oxford University Press, 218-240.

Tortora, Christina (2014b). 'On the relation between functional architecture and patterns of change in Romance clitic syntax' in M.-H. Côté \& E. Mathieu (eds.), Variation within and across Romance Languages. Amsterdam: John Benjamins, 331-348.

Tortora, Christina (2015a). A Comparative Grammar of Borgomanerese. New York: Oxford University Press.

Uriagereka, Juan (1995). 'Aspects of the syntax of clitic placement in Western Romance' Linguistic Inquiry 26: 79-123.

Vanelli, Laura (1989). I dialetti italiani settentrionali nel panorama romanzo. Roma: Bulzoni.

Vedovato, Diana (2009). 'Weak pronouns in Italian: Instances of a broken cycle?' in Cyclical Change, ed. by Elly van Gelderen. Amsterdam: Benjamins, 133-156.

Vedovato, Diana and Mariachiara Berizzi (2011). 'Enclisi pronominale alle preposizioni drio e sora in alcune varietà venete' Rivista Italiana di Dialettologia 35: 37-50.

Wolfe, Sam (2016). 'On the Left Periphery of V2 Languages' Rivista di Grammatica Generativa 38: $287-310$. 